\title{
Self-Assembly of Phosphate Fluorosurfactants in Carbon Dioxide
}

\author{
J ason S. Keiper, ${ }^{\dagger}$ J acqueline A. Behles, ${ }^{\dagger}$ Tracy L. Bucholz, ${ }^{\dagger}$ Ruma Simhan, ${ }^{\dagger}$ and \\ J oseph M. DeSimone*,t,
}

NSF Center for Environmentally Responsible Solvents and Processes, Department of Chemistry, University of North Carolina at Chapel Hill, Chape Hill, North Carolina 27599, and Department of Chemical Engineering, North Carolina State University, Raleigh, North Carolina 27695

\author{
Gary W. Lynn, George D. Wignall,* and Yuri B. Melnichenko
}

Solid State Division, Oak Ridge National Laboratory,§ Oak Ridge, Tennessee 37831

Henrich Frielinghaus

Forschunszentrum J ülich GmbH, Institut für Festkörperforschung, D-52425 J ülich, Germany

Received May 1, 2003. In Final Form: December 1, 2003

\begin{abstract}
Anionic phosphodiester surfactants, possessing either two fluorinated chains (F/F) or one hydrocarbon chain and one fluorinated chain (H/F), were synthesized and evaluated for solubility and self-assembly in liquid and supercritical carbon dioxide. Several surfactants, of both $\mathbf{F} / \mathbf{F}$ and $\mathbf{H} / \mathbf{F}$ types and having varied counterions, were found to be capable of solubilizing water-in- $\mathrm{CO}_{2}(\mathrm{~W} / \mathrm{C})$, via the formation of microemulsions, expanding upon the family of phosphatefluorosurfactants al ready found to stabilize W/C microemulsions. Small-angle neutron scattering was used to directly characterizethemicroemul sion particles at varied temperatures, pressures, and water loadings, reveal ing behavior consistent with previous results on W/C microemulsions.
\end{abstract}

\section{Introduction}

Carbon dioxide $\left(\mathrm{CO}_{2}\right)$ is presently considered the most promising "green-friendly" al ternative solvent. ${ }^{1} \mathrm{~N}$ onflammable, nontoxic, readily available, and inexpensive, $\mathrm{CO}_{2}$ is a useful solvent in both its compressed liquid and supercritical $\left(\mathrm{scCO}_{2} ; \mathrm{T}_{\text {critical }}=31.1^{\circ} \mathrm{C}, \mathrm{P}_{\text {critical }}=73.8\right.$ bar $)$ forms for a number of processes. ${ }^{2} \mathrm{Although} \mathrm{CO}_{2}$ sol utions are prepared in pressurized vessels, with simple control of pressure and temperature, a wide range of solvent densities (and, in turn, solvent qualities and solvation properties) are attainable. Carbon di oxide is also easily recyclable and can be evaporated from reaction vessels through simpledepressurization at ambient temperatures, allowing for low-energy, low-cost processing. Carbon dioxide is now used in extractions, cleaning systems, microelectronics devel opment, and polymer production. ${ }^{3}$

An important hurdle to the use of $\mathrm{CO}_{2}$ is the fact that many polar materials (such as water and ionic compounds) and high molecular weight polymers have low solubility in the medium ${ }^{4}$ and are referred to as " $\mathrm{CO}_{2}$ -

* To whom correspondence should be addressed.

† NSF Center for Environmentally Responsible Solvents and Processes, Department of Chemistry, U niversity of N orth Carolina at Chapel Hill.

‡ Department of Chemical Engineering, North Carolina State University Raleigh.

$\S$ Managed by UT-Battelle, LLC, under Contract DE-AC0500OR22725 with the U.S. Department of Energy

(1) DeSimone, J . M.; Kei per, J . S. Curr. Opin. Solid StateMater. Sci. 2001, 5, 333 .

(2) Kendall, J. L.; Canelas, D. A.; Young, J . L.; DeSimone, J. M. Chem. Rev. 1999, 99, 543.

(3) Wells, S. L.; DeSimone, J . Angew. Chem., Int. Ed. 2001, 40, 518.

(4) Consani, K. A.; Smith, R. D. J. Supercrit. Fluids 1990, 3, 51. phobic". ${ }^{5}$ To overcome this issue, surfactants must be employed to successfully disperse the normally incompatible solutes within $\mathrm{CO}_{2}$. New applications and increased proliferation of $\mathrm{CO}_{2}$ as a useful and versatile solvent in the chemical and biochemical realms depend to a great extent on the continued devel opment of surface-active molecules capable of dispersing or solubilizing $\mathrm{CO}_{2}$-phobic materials such as water. Fluorinated surfactants have served in this capacity for the stabilization of waterin- $\mathrm{CO}_{2}$ via the formation of microemulsions. ${ }^{6}$ Microemulsions are thermodynamically stable association colloids wherea minor fluid phaseis sequestered within a greater fluid phase, with surfactants adsorbed astride the two

(5) DeSimone, J . M.; Maury, E. E.; Mencel oglu Y. Z.; McClain, J . B.; Romack, T. J .; Combes, J. R. Science 1994, 265, 365.

(6) Harrison, K.; Goveas, J .; ohnston, K. P.; O'Rear, E. A. Langmuir 1994, 10, 3536. (b) J ohnston, K. P.; Harrison, K. L.; Clarke, M.J .; Howdle, S. M.; Heitz, M. P.; Bright, F. V.; Carlier, C.; Randolph, T. W. Science 1996, 271, 624. (c) Eastoe, J.; Bayazit, Z.; Martel, S.; Steytler, D. C.; Heenan, R. K. Langmuir 1996, 12, 1423. (d) Eastoe, J .; Cazelles, B. M. H.; Steytler, D. C.; Holmes, J . H.; Pitt, A. R.; Wear, T. J .; Heenan, R. K. Langmuir 1997, 13, 6980. (e) Zielinski, R. G.; Kline, S. R.; Kaler, E. W.; Rosov, N. Langmuir 1997, 13, 3934. (f) Holmes, J. D.; Bhargava, P. A.; Korgel, B. A.; J ohnston, K. P. Langmuir 1999, 15, 6613. (g) Ji, M.; Chen, X.; Wai, C. M.; Fulton, J . L. J . Am. Chem. Soc. 1999, 121, 2631. (h) J acobson, G. B.; Lee, C. T., J r.; J ohnston, K. P. J . Org. Chem. 1999, 64, 1201. (i) Eastoe, J .; Downer, A.; Paul, A.; Steytler, D. C. Rumsey, E.; Penfold, J .; Heenan, R. K. Phys. Chem. Chem. Phys. 2000, 2, 5235. (j) Lee, C. T.,, r r.; Bhargava, P.; J ohnston, K. P.J . Phys. Chem B 2000, 104, 4448. (k) Lee, C. T.,J r.j ohnston, K.P.; Dai, H.J ;Cochran, H. D.; Melnichenko, Y. B.; Wignall, G. D. J . Phys. Chem. B 2001, 105 3540. (I) Liu, Z.-T.; Erkey, C. Langmuir 2001, 17, 274. (m) Ohde, H.; Hunt, F.; Kihura, S.; Wai, C. M. Anal. Chem. 2000, 72, 4738. (n) Lee, D.; Hutchison, J. C.: DeSimone, J . M.; Murray, R. M. J . Am. Chem. Soc. 2001, 123, 8406, (n) Lee, C. T.,J r.; Psathas, P. A.; Ziegler, K.J .; ohnston, K. P.; Dai, H.J .; Cochran, H. D.; Mel nichenko, Y. B.; Wignall, G. D. J . Phys. Chem. B 2000, 104, 11094. 
Scheme 1. Synthesis of Phosphate Surfactants

F/F Surfactants

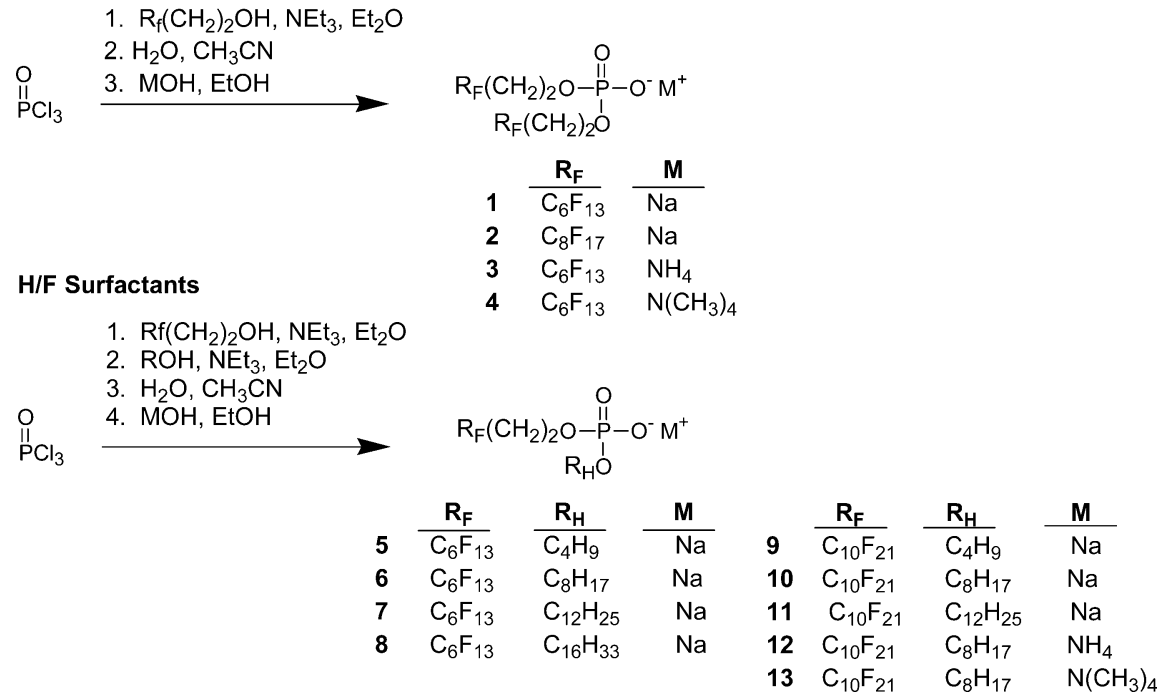

phases (often water and a hydrophobic solvent). ${ }^{7}$ The surfactants serve to reduce the interfacial tension, and in order tocarry out this task, themolecules must effectively pack about a curved surface while distributing appropriately between the phases of different polarities. Thus, both molecular geometry and makeup of the amphiphilic moieties play important roles. Only a few surfactant types have been used to form water-in- $\mathrm{CO}_{2}$ (W/C) mi croemulsions, most commonly perfluoropol yether carboxylates and dichained sulfonate fluorosurfactants. Fluorinated surfactants are parti cularly suitable for W/C microemulsions due to the " $\mathrm{CO}_{2}$-philicity"8 of the fluorinated chains.

Phosphateesters arean important family of surfactants that have many industrial applications. There are a handful of examples of the use of phosphate fluorosurfactants in $\mathrm{CO}_{2}$. Consani and Smith first reported that phosphatefluorosurfactants, in the form of a commercially available mixture, were capable of solubilizing small amounts of water in $\mathrm{CO}_{2}{ }^{4}$ Interestingly, the surfactant required water to dissolve in $\mathrm{CO}_{2}$. Wai and co-workers haveused a phosphateacid-derivatized perfluoropol yether as a cosurfactant with Aerosol-OT (AOT) to stabilize W/C microemulsions. ${ }^{6 g}, \mathrm{~m}$ This surfactant system allowed for voltammetric studies and inorganic particlesynthesis but was incapable of forming microemulsions as the sole surfactant. Recently, however, individual phosphate fluorosurfactants have been shown to form W/C mi croemulsions. Our groups, ${ }^{9}$ as well as that of Eastoe et al., ${ }^{10}$ reportedanionic phosphates capableof W/C microemulsion formation. In both studies, the surfactants allowed for considerable water content in the mi croemulsions (commonly described in terms of [water]/[surfactant] molar ratio, or $W_{0}$ ), and are thus promising materials for extending W/C microemulsions toa variety of applications.

In the present work we expand upon our initial report ${ }^{9}$ on the behavior of anionic phosphatefluorosurfactants in

(7) Handbook of Microemulsion Scienceand Technol ogy; Kumar, P., Mittal, K. L., Ed.; Marcel Dekker: New York, 1999.

(8) Maury, E. E.; Batten, H. J .; Killian, S. K.; Menceloglu, Y. Z.; Combes, J. R.; DeSimone, J. M. Polym. Prepr. 1993, 34, 664.

(9) Keiper, J. S.; Simhan, R.; DeSimone, J. M.; Wignall, G. D. Melnichenko, Y. B.; Frielinghaus, H. J . Am. Chem. Soc. 2002, 124 1834.

(10) Steytler, D. C.; Rumsey, E.; Thorpe, M.; Eastoe, J .; Paul, A.; Heenan, R. K. Langmuir 2001, 17, 7948. carbon dioxide. The surfactants either possess two fluorinated chains (F/F) or one fluorinated and one fully hydrocarbon chain (H/F). The H/F surfactants, in particular, were inspired by hybrid sulfate surfactants that were shown to stabilize W/C microemulsions. Aspects of the surfactant structures that render them promising candidates for microemulsion formation include the following: (1) A very hydrophilic headgroup region capable of strongly structuring surrounding water molecules, ${ }^{11}$ (2) $\mathrm{CO}_{2}$-philic fluorinated chains, and (3) Nominal "inverted cone" geometry that lends toward packing in negative curvatures. ${ }^{12}$

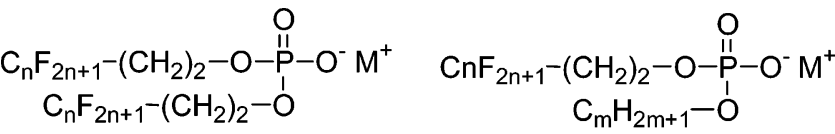

$$
\begin{aligned}
& \text { F/F H/F }
\end{aligned}
$$

The surfactants were synthesized and evaluated for solubilities in $\mathrm{CO}_{2}$ both in the absence and in presence of water via cloud point studies. It will be shown that several of the surfactants were capable of water uptake in $\mathrm{CO}_{2}$, to different extents, and that the $\mathbf{F} / \mathbf{F}$ and $\mathbf{H} / \mathbf{F}$ surfactants display very different behavior. Small angle neutron scattering (SANS) was used to directly confirm the formation of nanometer-sized microemulsions and to quantify temperature and pressure-induced changes in the size of their nanodroplet cores. Prospective future studies and potential applications will be discussed.

\section{Results and Discussion}

Synthesis. The present surfactants were prepared following the general procedures shown in Scheme 1. Protocols for $\mathbf{F} / \mathbf{F}$ and $\mathbf{H} / \mathbf{F}$ surfactant types involved reaction of stoichiometric amounts of Iong-chain alcohols with phosphorus oxychloride in the presence of triethylamine base, in anhydrous diethyl ether $.^{13} \mathbf{H} / \mathbf{F}$ surfactants synthesis required addition of theless reactivefluorinated

(11) Tamaki, K et al. Bull. Chem. Soc. J pn. 1987, 60, 1225

(12) I sraelachvili, J . N. I ntermolecular and Surface F orces, 2nd ed.; Academic Press: New York, 1999.

(13) Krafft, M.-P.; Rolland, J .-P.; Vierling, P.; Riess, J . G. New. J Chem. 1990, 14, 869. 
alcohol first, followed by the hydrocarbon alcohol. U pon hydrolysis in acetonitrile, the neutral compounds were obtained in unoptimized yields in the range of $30-60 \%$ and converted to their sodium salts with an equivalent of aqueous sodium hydroxide in ethanol. ${ }^{14}$ Ammonium and tetramethylammonium salts were obtained by reaction with an equivalent of aqueous ammonium hydroxide and aqueous tetramethylammonium hydroxide in ethanol, respectively. Surfactant purity was determined by ${ }^{1} \mathrm{H},{ }^{19} \mathrm{~F}$, and ${ }^{31}$ P NMR and elemental analysis.

Solubility and Phase Behavior. Phase behavior in $\mathrm{CO}_{2}$ is commonly evaluated by determining so-called "cloud points" as a function of temperature and pressure. In brief, a typical experiment entails first dissolving the solute(s) in $\mathrm{CO}_{2}$ within the confines of a stainless steel, variabl evolume view cell. By varying the vol ume with an adjustable piston, one can reduce the pressure isothermally, allowing the solution to pass through a pressure transition fromclarity to phaseseparation. Thetransition is reversible upon repressurization. A cloud point is a somewhat subjective phenomenon as it is visually assessed, and there are intermediate changes in solution appearance that can occur. For instance, the solution can take on a deep orangecol or, presumably duetosignificant light scattering of agglomerating particles at pressures just above the cloud point. ${ }^{3 j}$ In the present study, cloud points were defined as the reproducible onset of a fully opaque solution and were taken on the cooling cycle over a range of temperatures. From these points, phase diagrams can be derived, defining the boundaries of solution stabilities.

Water uptake was evaluated for $2.5 \mathrm{wt} \%$ solutions of surfactants in $\mathrm{CO}_{2}$ at varied $\mathrm{W}_{\mathrm{o}}$ values. ${ }^{15} \mathbf{F} / \mathbf{F}$ surfactants $\mathbf{1}$ and 2, insoluble in dry $\mathrm{CO}_{2}$, formed clear solutions in the presence of water. This behavior is consistent with Consani and Smith's previous findings with commercial anionic phosphate fluorosurfactants. ${ }^{4}$ Figure 1 depicts cloud point measurements for surfactant 1 and $\mathbf{2}$ in graphs $A$ and $B$, respectively. Two important items stand out in these results. First, both surfactants were capable of dissolving high loadings of water in $\mathrm{CO}_{2}$, indicative of microemulsion formation. (Thepresence of discretewater pools for microemulsions of $\mathbf{1}$ was previously confirmed via solvatochromatic dye studies. ${ }^{9}$ ) Second, while surfactant 1 solutions provided linear cloud point trends over the studied temperature range, solutions of surfactant $\mathbf{2}$ either phase separated or had cloud point profiles that trended upward at temperatures below $35{ }^{\circ} \mathrm{C}$. This surfactant pair is another instance whereel ongated $\mathrm{CO}_{2-}$ philic chains (surfactant $\mathbf{2}$ has longer fluorinated units than surfactant 1) do not contribute to enhanced microemulsion stability. Erkey et al. observed similar results for sul fosuccinate fluor osurfactants. ${ }^{61}$

Water uptake was al so evaluated for $2.5 \mathrm{wt} \%$ sol utions of surfactants using ammonium-based counterions. As opposed to surfactants having sodium counterions, surfactants possessing ammonium or tetramethylammonium counterions were soluble in dry $\mathrm{CO}_{2}$ and formed clear solutions (data not shown).

In Figure2, higher values of water uptakeareexamined for surfactants $\mathbf{1}, \mathbf{3}$, and $\mathbf{4}$. Graphs A and B depict the cloud point profiles at $W_{0}=34$ and 45 , respectively. In graph A, surfactants $\mathbf{1}$ and $\mathbf{3}$ had similar profiles while surfactant $\mathbf{4}$ showed much different behavior. Surfactant

(14) Romsted, L. S.; Zanette, D. J . Phys. Chem. 1988, 92, 4690.

(15) For cloud point data and discussion of "dry" $\mathrm{CO}_{2}$ solutions of the anionic surfactants and their neutral hydrogen phosphate precursors, please see the Supporting I nformation. Others have demonstrated the potential for micellization of surfactants in $\mathrm{CO}_{2}$ in theabsence of water. ${ }^{16}$
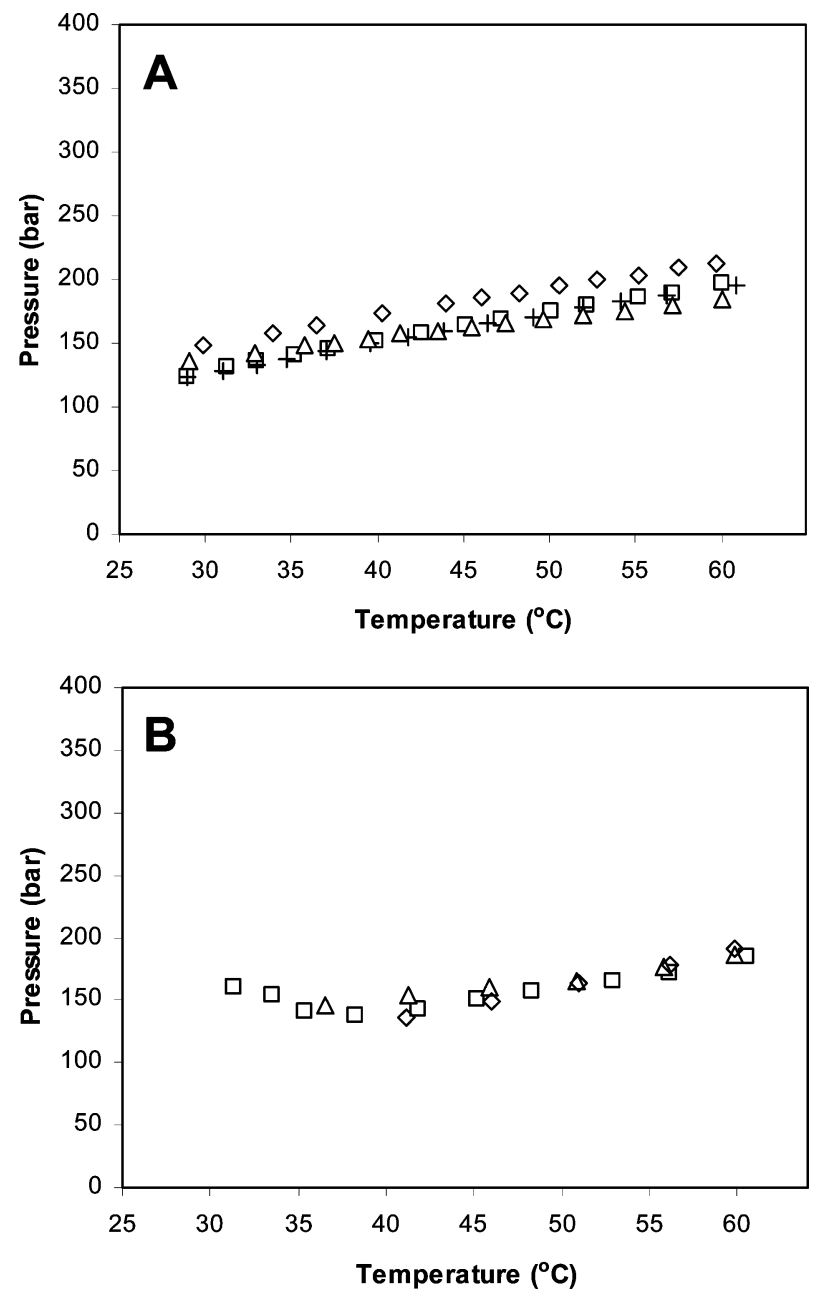

Figure 1. Cloud points of 2.5 wt \% solutions of $\mathbf{F} / \mathbf{F}$ anionic fluorosurfactants with various water loadings (uncorrected $\mathrm{W}_{\mathrm{o}}$ ) and sodium counterions: graph A, surfactant 1, $W_{0}=11(\triangle)$, $\mathrm{W}_{\mathrm{o}}=17(+), \mathrm{W}_{\mathrm{o}}=36(\square), \mathrm{W}_{\mathrm{o}}=45(\diamond)$; graph $\mathrm{B}$, surfactant 2, $\mathrm{W}_{\mathrm{o}}=11(\Delta), \mathrm{W}_{\mathrm{o}}=33(\square), \mathrm{W}_{\mathrm{o}}=46(\diamond)$.

$\mathbf{4}$ also showed varying behavior in graph $\mathbf{B}$ as compared to surfactant $\mathbf{1}$, while surfactant $\mathbf{3}$ was not able to form microemulsions at this water loading. Again, thebehavior of surfactant $\mathbf{4}$ may indicate a changein thetype of micelle formed in solution, such as from a more spherical micelle to a worm or threadlike micelle.

$\mathbf{H} / \mathbf{F}$ surfactants were also evaluated for cloud point behavior at 2.5 wt \%. Surfactants $\mathbf{5}$ through $\mathbf{8}$, with $-\left(\mathrm{CH}_{2}\right)_{2} \mathrm{C}_{6} \mathrm{~F}_{13}$ fluorinated chains, were incapable of forming homogeneous solutions in the presence of water. Anal ogues $\mathbf{9}$ through 11, with longer fluorinated $-\left(\mathrm{CH}_{2}\right)_{2} \mathrm{C}_{10} \mathrm{~F}_{21}$ units, were capable of water uptake, to varying degrees. Figure 3 depicts the cloud point profile for surfactant $\mathbf{1 0}$ (for comparison, please see the Supporting Information for the cloud point curves for surfactants 9 and 11). In general, as the hydrocarbon chain length was increased, more water uptake was possible. (Below we report SANS measurements for surfactant $\mathbf{1 0}$ that provide evidence for the formation of discrete droplets.) Another possible factor is for surfactants $\mathbf{1 0}$ and 11, higher loadings simply facilitated surfactant dissolution, or perhaps looser surfactant packing about thewater phase, thus al lowing for less unfavorable contact between the hydrocarbon and fluorinated chains. As with all surfactant solutions, however, a true explanation for the observed behavior likely lies in a complex balance of numerous competing and cooperative forces. 

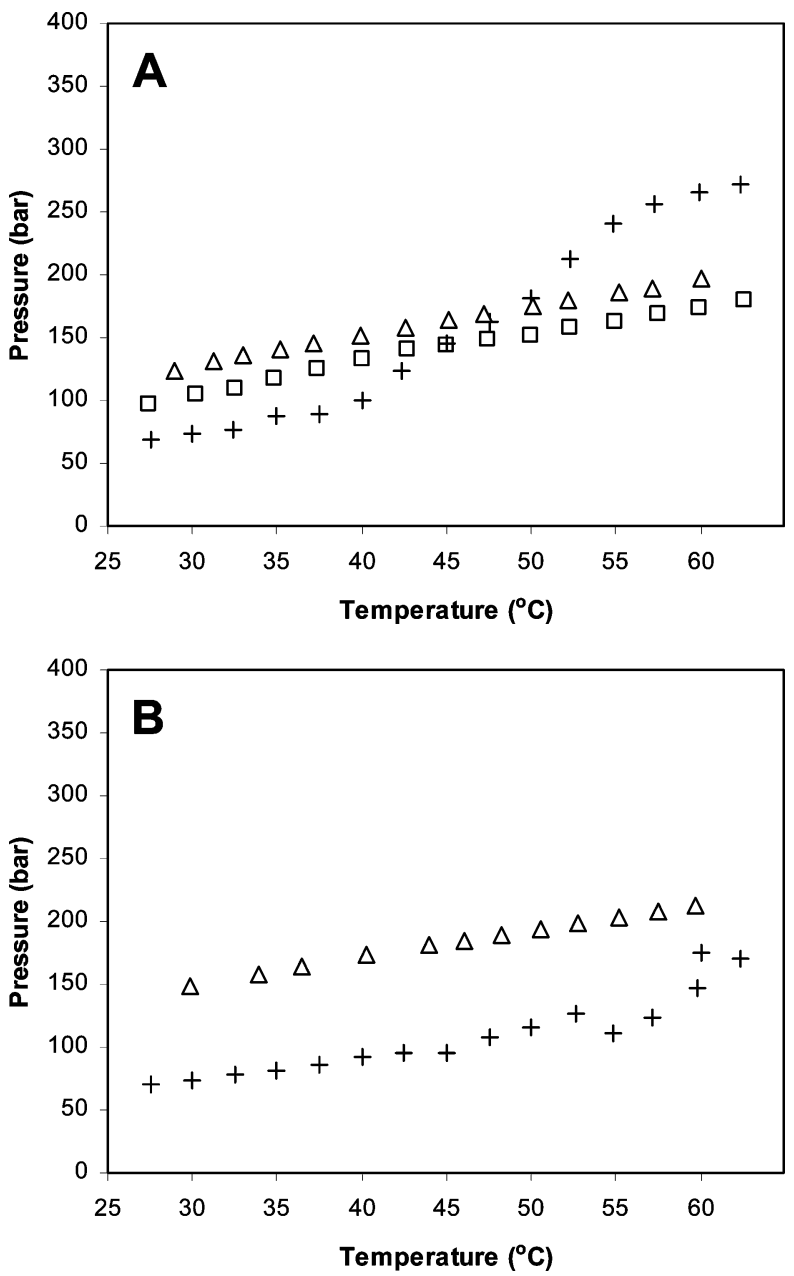

Figure 2. Cloud points of 2.5 wt $\%$ solutions of $\mathbf{F} / \mathbf{F}$ anionic fluorosurfactants at constant $\mathrm{W}_{\mathrm{o}}$ (uncor rected $\mathrm{W}_{\mathrm{o}}$ ) with varying counterions: surfactant $\mathbf{1}(\triangle)$; surfactant $\mathbf{3}(\square)$; surfactant $\mathbf{4}$ $(+)$; graph $A, W_{0}=34$; graph $B, W_{0}=45$

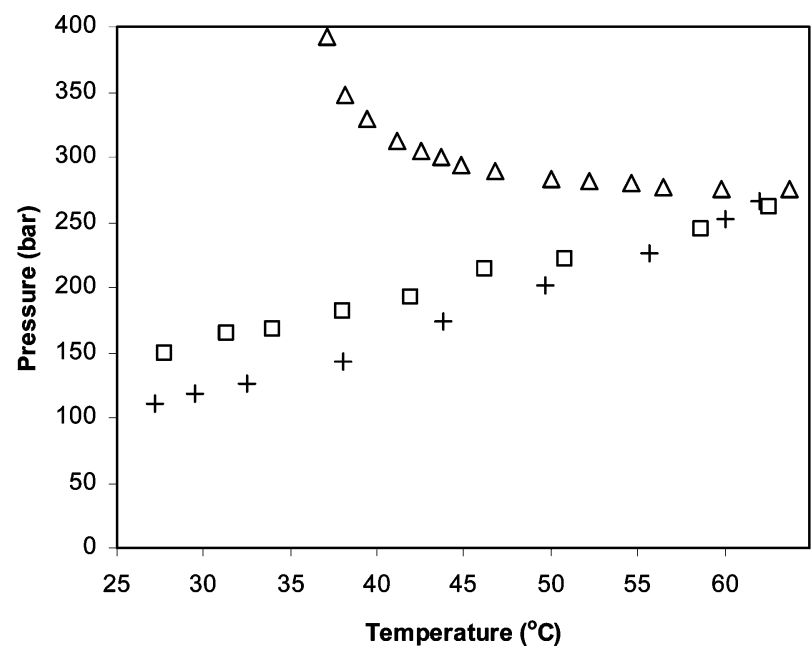

Figure 3. Cloud points of 2.5 wt \% solution of $\mathbf{H} / \mathbf{F}$ anionic fluorosurfactant $\mathbf{1 0}$ with various water loadings (uncor rected $\left.\mathrm{W}_{\mathrm{o}}\right): \mathrm{W}_{\mathrm{o}}=11(\triangle) ; \mathrm{W}_{\mathrm{o}}=17(+) ; \mathrm{W}_{\mathrm{o}}=34(\square)$.

Finally, in Figure 4, the influence of the counterion is examined for $\mathbf{H} / \mathbf{F}$ surfactants, and thecloud point profiles for surfactants 10, 12, and $\mathbf{1 3}$ are shown at $\mathrm{W}_{\mathrm{o}}=11$. In each of the water loadings, the behavi or of surfactant $\mathbf{1 2}$ did not show any sharp increases or decreases in solubility. Surfactants 10 and 13, however, were shown to exhibit similar behavior, with surfactant $\mathbf{1 3}$ being themore readily

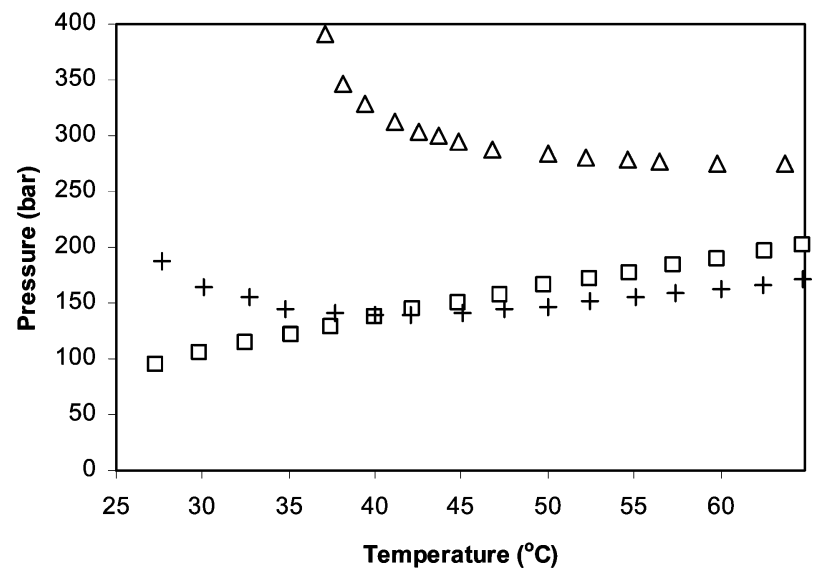

Figure 4. Cloud points of 2.5 wt \% solutions of $\mathbf{H} / \mathbf{F}$ anionic fluorosurfactants at constant $\mathrm{W}_{0}=11$ (uncorrected $\mathrm{W}_{0}$ ): surfactant 10, $(\triangle)$; surfactant 12, $(\square)$; surfactant 13, (+).

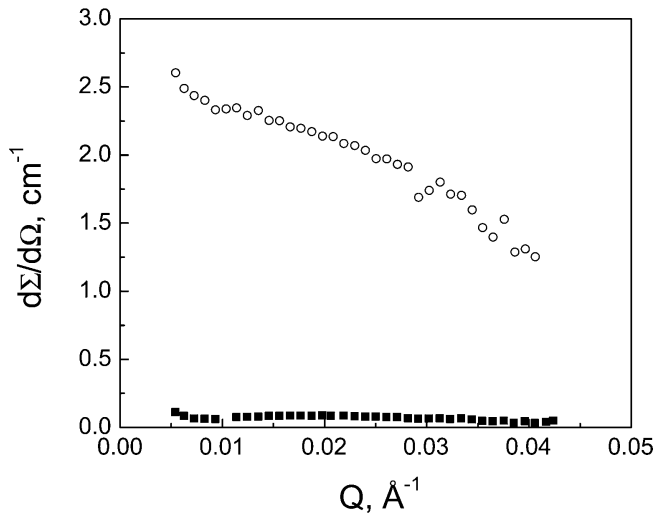

Figure 5. SANS cross sections for surfactant 1: (口) $5.8 \mathrm{wt} \%$ swollen with $\mathrm{D}_{2} \mathrm{O}\left(\mathrm{W}_{\mathrm{o}}=12.3\right.$, uncorrected) and (O) $5.7 \mathrm{wt} \%$ swollen with $\mathrm{H}_{2} \mathrm{O}\left(\mathrm{W}_{\mathrm{o}}=12.5\right.$, uncorrected).

soluble of the two. With an increase in water loading, the solubility of the surfactants changed markedly (as shown in Figure 5 of Supporting I nformation at $W_{0}=17$ ). Overall, this is the first report where the effect of the counterion on the surfactant was systematically studied for its corresponding effect on the phase behavior in $\mathrm{CO}_{2}$. The effects of the changes in phase behavior seen with varying counterions may be explained by the counterion being abletoaffect thestability of thestructurein solution based on its relative hydrophilicity as well as the strength of its binding to the headgroup of the surfactant.

Small-Angle Neutron Scattering (SANS). SANS measurements were carried out on the KWS2 SANS facility ${ }^{17}$ at the F RJ 2 reactor in J ülich, Germany, with a $45 \times 45 \mathrm{~cm}^{2}$ area detector with cell size ca. $0.8 \times 0.8 \mathrm{~cm}^{2}$ and a wavelength $(\lambda)$ of $6 \AA$, with a wavelength polydispersity $(\Delta) \lambda / \lambda=0.2$. A sample-detector distance of $8 \mathrm{~m}$ was used to give an overall range of momentum transfer $0.0054<\mathrm{Q}=4 \pi \lambda^{-1} \sin \theta<0.042 \AA^{-1}$, where $2 \theta$ is the angl e of scatter. The experiments were conducted in a cell that has been used extensively for previous neutron scattering experiments $\left(23.1 \mathrm{~mm}\right.$ path length, $5.6 \mathrm{~cm}^{3}$ volume) $)^{18,19}$ and due to the high penetrating power of

(16) Eastoe, J .; Paul, A.; Nave, S.; Steytler, D. C.; Robinson, B. H. Rumsey, E.; Thorpe, M.; Heenan, R. K. J . Am. Chem. Soc. 2001, 123, 988.

(17) Neutronenstreuexperimente am F RJ 2 in J ülich, 1997 (English and German texts are available from the Forschungszentrum J ülich Germany).

(18) McClain, J .; Londono, J . D.; Chillura-Martino, D.; Triolo, R.; Betts, D. E : Canelas, D. A.; Cochran, H. D.: Samulski, E. T.; DeSimone J. M.; Wignall, G. D. Science 1996 274, 2049. 
neutrons, the beam passed through two $\sim 1 \mathrm{~cm}$. thick sapphire windows with virtually no parasitic scattering or attenuation (cell transmission 93\%). All data sets were corrected for instrumental backgrounds ${ }^{18,19}$ and normalized to an absolute $( \pm 4 \%)$ differential cross section per unit sampl evolume ( $\mathrm{d} \Sigma / \mathrm{d} \Omega(\mathrm{Q})$ in units of $\mathrm{cm}^{-1}$ ) by means of precalibrated secondary standards. ${ }^{20}$ Depending on temperatureand solvent density, small amounts of water dissolve in $\mathrm{CO}_{2}$ (up to about $0.2 \mathrm{wt} \%$ ). As with previous work in the literature, ${ }^{6 i}$ all $W_{0}$ values reported here are based upon the amounts of surfactant and water added to the cell for each experiment and are uncorrected for this small effect.

The data were therefore analyzed as described previously ${ }^{18,19}$ and the sol utions wererepresented as a collection of polydisperse particles, assuming no orientational correlations, and the coherent differential scattering cross section is given by eq 1

$$
\frac{\mathrm{d} \Sigma}{\mathrm{d} \Omega}(\mathrm{Q})=\mathrm{N}_{\mathrm{p}}\left[\left\langle|\mathrm{F}(\mathrm{Q})|^{2}\right\rangle+|\langle\mathrm{F}(\mathrm{Q})\rangle|^{2}(\mathrm{~S}(\mathrm{Q})-1)\right]+\mathrm{B}
$$

where $N_{p}$ is the number density of particles, $S(Q)$ is the structure function arising from interparticle scattering, and $B$ is the background from $\mathrm{CO}_{2}\left(\sim 0.04 \mathrm{~cm}^{-1}\right)$. Spherical particles with a centrosymmetric distribution of scattering length density may be modeled by concentric shells, 18,19 and for a core/shell micelle the intraparticle term in eq 1 may be expressed as

$$
\left\langle|F(Q)|^{2}\right\rangle=\int\left|F\left(Q, R_{1}\right)\right|^{2} f\left(R_{1}\right) d R_{1}
$$

where $R_{1}$ is the radius of a core, which occurs within the distribution of core radii with a normalized frequency of $f\left(R_{1}\right)$. The form factor of a particle with coreradius $R_{1}$ and outer radius $R_{2}$ is given by

$$
\begin{gathered}
F(Q, R)=(4 \pi / 3)\left[R_{1}^{3}\left(\rho_{1}-\rho_{2}\right) F_{0}\left(Q_{1}\right)+\right. \\
\left.R_{2}{ }^{3}\left(\rho_{2}-\rho_{s}\right) F_{0}\left(Q_{2}\right)\right] \\
F_{0}(x)=\frac{3}{x^{3}}(\sin x-x \cos x)
\end{gathered}
$$

Several particle shapes have been used to calculate the intraparticle term (or form factor) and in general for micelles in $\mathrm{CO}_{2}$, the best fits have been given by a spherical core-shell model with a Schultz distribution ${ }^{6 i, 10,18,19}$ of particle sizes

$$
\begin{gathered}
f\left(R_{1}\right)=\frac{(Z+1)^{Z+1} X^{Z} \exp [-(Z+1) X]}{\overline{R_{1}} \Gamma(Z+1)} \\
Z=\frac{1-\left(\sigma / \overline{R_{1}}\right)^{2}}{\left(\sigma / \overline{R_{1}}\right)^{2}} \\
X=R_{1} / \overline{R_{2}}
\end{gathered}
$$

where $\sigma^{2}$ is the variance of the distribution, $\mathrm{Z}$ is the breadth parameter, and $\rho_{1}, \rho_{2}$, and $\rho_{\mathrm{s}}$ are the scattering length densities (SLDs) of the core, shell, and solvent, respectively. As pointed out by Eastoe, Steytler, and co-workers, ${ }^{6 i}$ the SLD of $\mathrm{D}_{2} \mathrm{O}\left(\sim 6.4 \times 10^{10} \mathrm{~cm}^{-2}\right)$ is much higher than

(19) Triolo, F.; Triolo, A.; Triolo, R.; Londono, J . D.; Wignall, G. D.; McClain, J . B.; Betts, D. E.; Wells, S.; Samulski, E. T.; DeSimone, J. M. Langmuir 2000, 16 (2), 416.

(20) Wignall, G. D.; Bates, F. S. J . Appl. Crystallogr. 1986, 20, 28. the SLDs of $\mathrm{CO}_{2}$ or the surfactants, both of which are $\sim 2$ $\times 10^{-2} \mathrm{~cm}^{-2}$. Thus, the SLDs of the surfactant shell and $\mathrm{CO}_{2}$ solvent are essentially matched $\left(\rho_{2} \sim \rho_{\mathrm{s}}\right)$ and the scattering comes principally from the contrast between the $\mathrm{D}_{2} \mathrm{O}$ core and $\mathrm{CO}_{2}$. The particle form factor (defined as $P(Q)$ in ref 9 ), therefore reduces to a Bessel function representing a spherical core $(P(0)=1)$, and the water pools can be sized6i in terms of a core radius, $R_{1}$. This is illustrated in Figure 5 which shows the cross sections for solutions of 5.8 wt $\%$ surfactant 1 swollen with $\mathrm{D}_{2} \mathrm{O}\left(\mathrm{W}_{0}\right.$ $=12.3)$ and 5.7 wt \% surfactant 1 swollen with $\mathrm{H}_{2} \mathrm{O}\left(\mathrm{W}_{0}\right.$ $=12.2$ ), both at 173 bar after subtracting the $\mathrm{CO}_{2}$ background. It may be seen that the cross section ( 0.06 $\mathrm{cm}^{-1}$ ) from the $\mathrm{H}_{2} \mathrm{O}$-swollen material is of the same order as the incoherent background and well over an order of magnitude less than the coherent cross section of the $\mathrm{D}_{2} \mathrm{O}$ swollen solution $\left(\mathrm{d} \Sigma / \mathrm{d} \Omega(0) \approx 3 \mathrm{~cm}^{-1}\right)$. Thus, the majority of the scattering comes from the deuterium-labeled nanodropl ets, which form the core of the microemulsions.

In our initial report, ${ }^{9}$ particle interactions were neglected to a first approximation $(\mathrm{S}(\mathrm{Q}) \sim 1$ ) and $\mathrm{P}(\mathrm{Q})$ was approximated ${ }^{21}$ by $\mathrm{P}(\mathrm{Q}) \cong \exp \left[\left(-\mathrm{QR}_{\mathrm{g}}\right)^{2} / 3\right]$, where $\mathrm{R}_{\mathrm{g}}$ is the radius of gyration (i.e., theroot mean square $(\mathrm{rms})$ distance of all scattering elements from the center of gravity, $R_{\mathrm{g}}{ }^{2}$ $=\Sigma \mathrm{f}_{\mathrm{k}} \mathrm{r}_{\mathrm{k}}{ }^{2} / \Sigma \mathrm{f}_{\mathrm{k}}$, and the summation runs over all scattering elements, k, thus, typical (Guinier) plots of $\ln [\mathrm{I}(\mathrm{Q})]$ vs $\mathrm{Q}^{2}$ arelinear, ${ }^{9}$ with slope $\left(R_{g}{ }^{2}\right) / 3$ ) and the corresponding core radii are given by $R_{1}=(5 / 3)^{0.5} R_{\mathrm{g}}$. In this paper, we extend the initial analysis and allow for polydispersity and also inter particleinteractions between thedroplets, which can cause $S(Q)$ to depart from unity in eq 1 . Following the formalism employed by Steytler, ${ }^{10}$ Eastoe, ${ }^{6 c, i}$ and Lee ${ }^{6 k, n}$ and co-workers, S(Q) was modeled via an attractive Ornstein-Zernicke structure factor, characterized by a correlation length $\xi$ and $\mathrm{S}(0)$

$$
\mathrm{S}(\mathrm{Q})=1+\frac{\mathrm{S}(0)}{\left(1+\mathrm{Q}^{2} \xi^{2}\right)}
$$

Equation 5 has previously been applied ${ }^{6 i, c, 10}$ to account for interactions for surfactant concentrations $\sim 0.05 \mathrm{~mol}$ $\mathrm{dm}^{-3}$, and in this work the vast majority of samples were in a similar concentration regime $\left(<0.04 \mathrm{~mol} \mathrm{dm}^{-3}\right)$, with the exception of a few samples discussed below. SANS data were therefore analyzed initially assuming that particle-particle interactions were negligible $(\mathrm{S}(0) \approx 0$ ), as it has been previously observed ${ }^{6 i}$ that their effect is small for the values of $\mathrm{W}_{0}$ studied $\left(4<\mathrm{W}_{0}<20\right)$ in this concentration regi me, and that in general, $\mathrm{S}(\mathrm{Q})$ departed from unity only for high values $\left(\mathrm{W}_{0}>30\right)$ of the water/ surfactant ratio. Allowancefor particle polydispersity was made via eq 4 and on average this reduced the core radius by typically $20 \%$ from values derived from the Guinier formalism ${ }^{21}$ used in the initial interpretation. ${ }^{9}$ Allowing theSchultz breadth parameter to "float" generally resulted in values in the range $20<Z<30$ or $0.18<\sigma / \mathbf{R}_{1}<0.22$, and similar polydispersity parameters have been observed ${ }^{6,10}$ for other micelles formed by fluorosurfactants in $\mathrm{CO}_{2}$. For a few systems with the highest values of $\mathrm{W}_{0}$ (19.4) and $\mathrm{D}_{2} \mathrm{O}$ content (up to 4.4 vol \%), $\mathrm{S}(0)$ was also allowed to "float", along with the correlation length, $\xi$. The latter generally gave values typically $70-100 \AA$, and theanalysis was found to beinsensitive to $\xi$ in this range, as previously observed. ${ }^{6 i}$ Fitting $\mathrm{R}_{1}, \mathrm{~S}(0)$, and $\xi$, or fitting $\mathrm{R}_{1}, \mathrm{~S}(0)$ with fixed $\xi \sim 100 \AA$, generally gave values in the

(21) Guinier, A.; Fournet, G. Small-Angle Scattering of X-rays; Wiley: New York, 1955. 


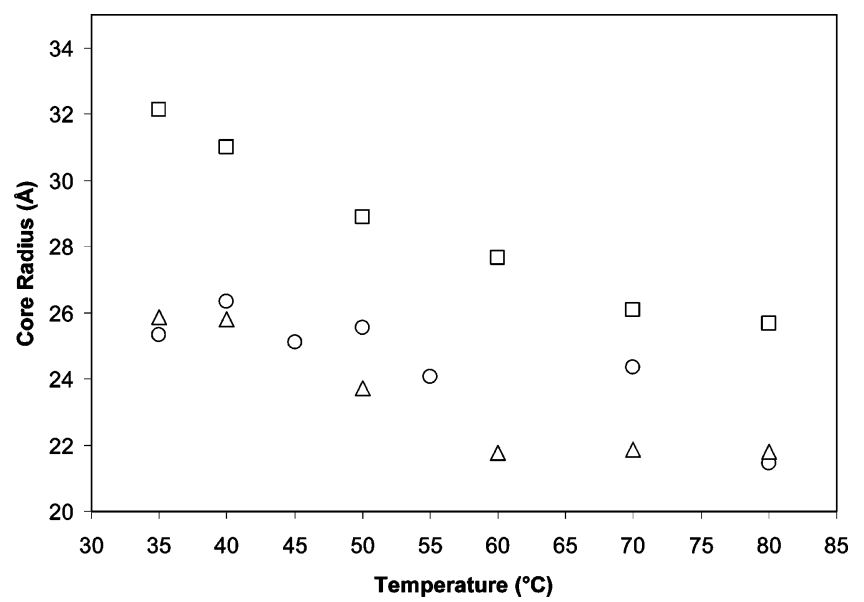

Figure 6. Surfactant $1: R_{1}$ vs $T$ at 173 bar, for $W_{0}=19.4(\square)$, $\mathrm{W}_{\mathrm{o}}=6.0(\mathrm{O})$, and $\mathrm{W}_{\mathrm{o}}=3.9(\triangle)$, all uncorrected.

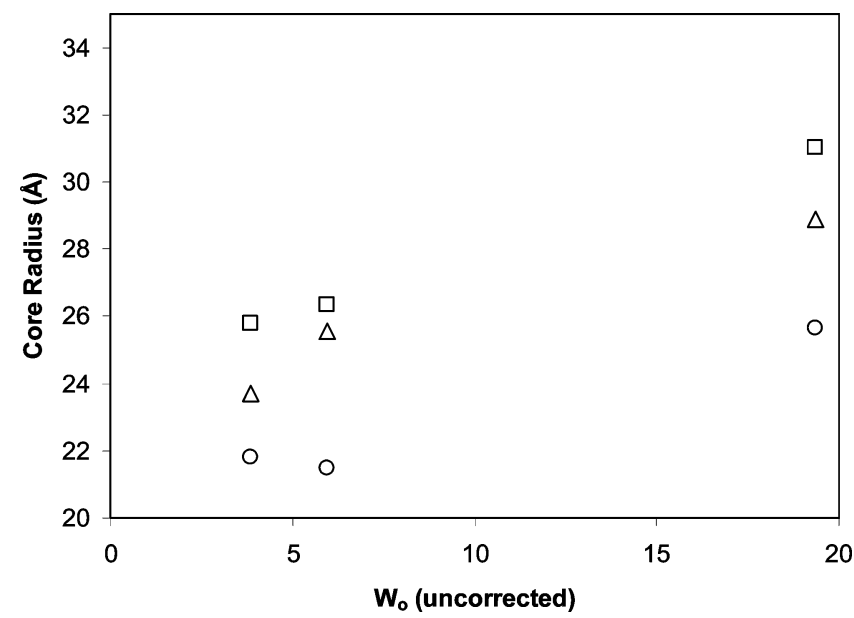

Figure 7. Surfactant 1: $R_{1}$ vs uncorrected $W_{0}$ at 173 bar at $40^{\circ} \mathrm{C}(\square), 50{ }^{\circ} \mathrm{C}(\triangle)$, and $80^{\circ} \mathrm{C}(O)$.

range $-0.1<\mathrm{S}(0)<0.1$ confirming that the effect of interactions was small, even for the highest values of $\mathrm{W}_{0}$ and the volume fraction (4.5\%) of $\mathrm{D}_{2} \mathrm{O}$, as expected from previous studies of similar systems. $6 i, 10$ Thus, allowance for interactions, generally changed $R_{1}$ by less than $3 \%$, which is less than the overall uncertainty in $R_{1}( \pm 2 \AA)$ generally expected from SANS analysis for similar systems.

The main conclusions emerging from the analysis are as follows: Figure 6 for surfactant 1 shows that for fixed initial pressure (172 psi) the core radius, $\mathrm{R}_{1}$, falls 20 $30 \%$ as the temperature is raised from 35 to $80^{\circ} \mathrm{C}$. This parallels theresults of Eastoeet al. (seeF igure 9 from ref 6i). Figure 7 shows that for fixed pressure, $R_{1}$ increases around $20 \%$ as $W_{0}$ increases from 3.9 to 19.4 , also paralleling the results of Eastoe et al. (see Figure 9 from ref 6i). Figure8 shows that for fixed $W_{0}=12.3$ (uncorrected) and temperature $\left(24{ }^{\circ} \mathrm{C}\right), \mathrm{R}_{1}$ falls around $20 \%$ as the pressure increases from 173 to 380 bar, also consistent with the results of Eastoe et al. (see Figure 9 from ref 6i). Such behavior is consistent with a general increase in water solubility with increased $\mathrm{CO}_{2}$ density, which would lead to "squeezing water out of themicelles" and rendering them smaller. It was found that for fixed pressure (414 bar), temperature $\left(35^{\circ} \mathrm{C}\right)$, and (initial ) $\mathrm{W}_{\mathrm{o}}=12.3$, the core radius increases with the volume $\%$ of $\mathrm{D}_{2} \mathrm{O}$ (shown in Figure 6 of Supporting Information). This trend is reproduced for other pressures (e.g., 173, 310, and 414 bar) and temperatures (e.g., $24^{\circ} \mathrm{C}$ ) not shown. Finally, Figure 9 shows that at for fixed (initial) pressure, the core

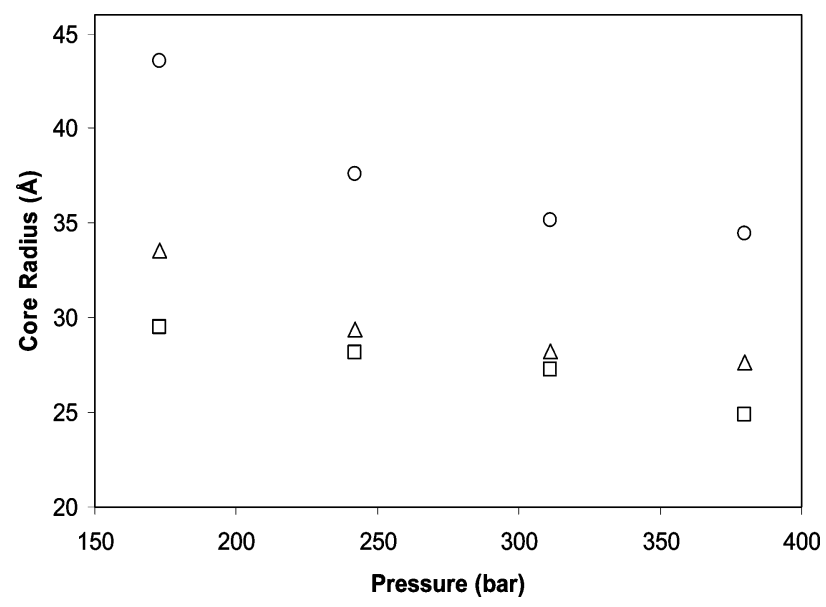

Figure 8. Surfactant $1: R_{1}$ vs $P$ at $24{ }^{\circ} \mathrm{C}$ and $W_{\circ}=12.3$ (uncorrected), and volume $\% \mathrm{D}_{2} \mathrm{O}=4.4 \%(O), 1.5 \%(\triangle)$, and $0.75 \%(\square)$
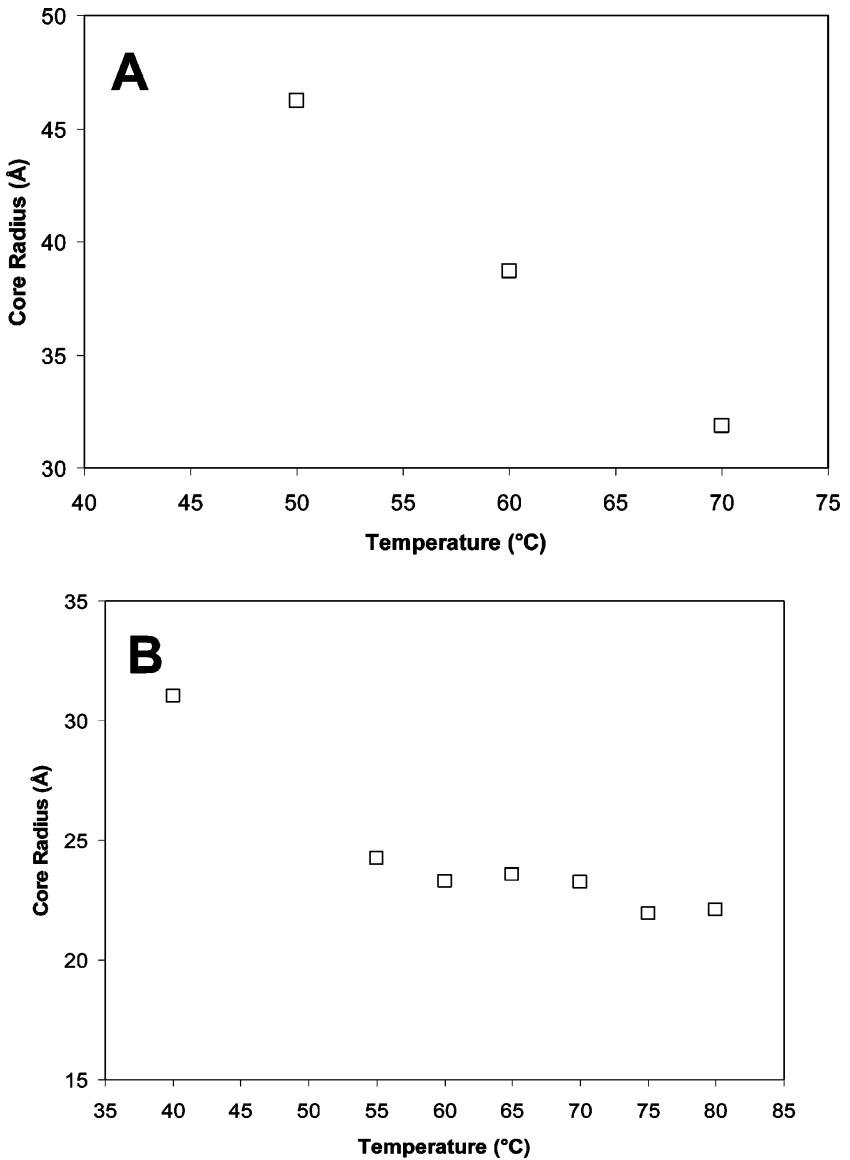

Figure 9. Graph $A$ : surfactant $8, R_{1}$ vs $T$ at 318 bar and $W_{\circ}$ $=12.6$ (uncorrected). Graph B: surfactant 2, $\mathrm{R}_{1}$ Vs T at 242 bar and $\mathrm{W}_{\mathrm{o}}=12.3$ (uncorrected).

radius, $\mathrm{R}_{1}$, falls $\sim 30 \%$ as the temperature is raised from 50 to $70{ }^{\circ} \mathrm{C}$ for surfactants $\mathbf{1 0}$ and $\mathbf{2}$, respectively, again paralleling the results of Eastoe et al. (see Figure 9 in ref 6i).

It is important to emphasize that as progress continues on the fundamental development and characterization of new surfactants for $\mathrm{CO}_{2}$, an eye should be kept toward applications that will spark continued interest in this emerging area of technology. In this regard, as a final note we report that several of the $\mathbf{H} / \mathbf{F}$ surfactants, including surfactant 10, formed bilayer vesiclestructures in aqueous solution. Figure 10 depicts micrographs of 

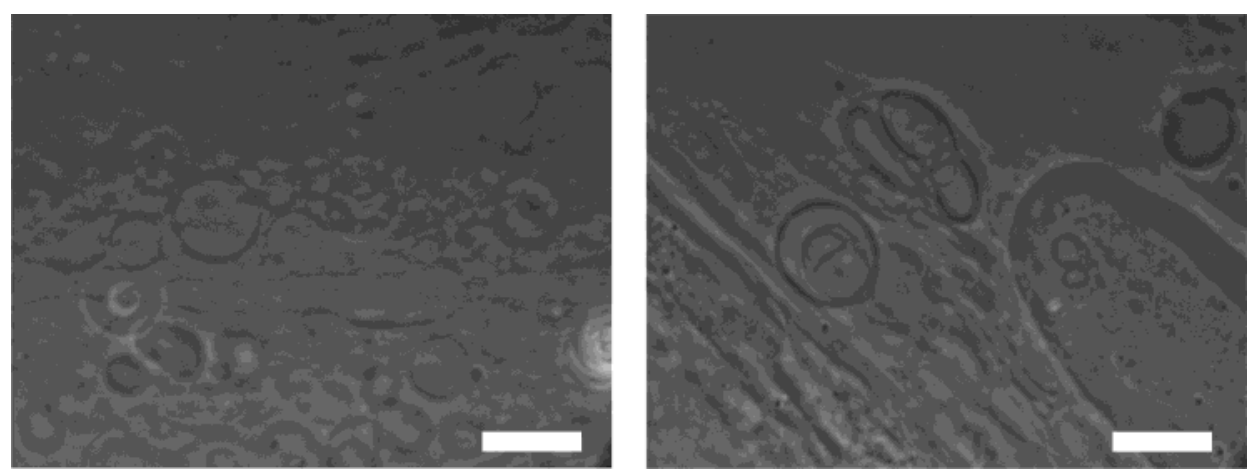

Figure 10. Microscopic bilayer vesicles of surfactant 10 in pure water at $25^{\circ} \mathrm{C}$. Bars $=30 \mu \mathrm{m}$.

micrometer-scale giant vesicles 22 that formed spontaneously when hydrated in pure water at room temperature. Vesicles (also known as liposomes) have been widely studied for drug del ivery applications, and dense $\mathrm{CO}_{2}$ has recently been reported as a processing solvent for vesicle formation through reverse phaseevaporation. ${ }^{23}$ Surfactant 10, having both the capacity for stabilizing W/C microemulsions and forming vesicles in water, would seem to hold potential as a "dual" media surfactant capable of forming drug-encapsulating vesicles through W/C microemulsion intermediate assemblies.

\section{Conclusions}

Anionic phosphate fluor osurfactants have been shown to form W/C microemulsions, with the phase behavior dependent upon surfactant chain lengths, the nature of the chains (i.e., two fluorinated chains versus one fully hydrocarbon and one partially fluorinated chain), and the nature of the counterion (sodium, ammonium, and tetramethylammonium). SANS measurements on the microemulsions, modeled using the spherical core-shell model based upon a Schultz distribution, reveal ed particle radii trends (as a function of water loadings, pressure, and temperature) consistent with previous studies on similar W/C systems. Ongoing studies include molecular dynamics simulations, ${ }^{24}$ NMR diffusion studies, and interfacial tension (IFT) measurements of the phosphate fluorosurfactants in $\mathrm{CO}_{2}$. F uture studies may probe the impact of different counterions, varied degrees of chain fluorination, and mixed surfactant systems on microemulsion behavior.

\section{Experimental Section}

Synthesis. Phosphorus oxychl oride, triethylamine, 1-butanol, 1-octanol, 1-dodecanol, and 1-hexadecanol were purchased from Aldrich. Anhydrous diethyl ether was from Mallinckrodt, and acetonitrilefrom Fisher. The F/F and $\mathbf{H} / \mathbf{F}$ surfactant series were synthesized as described above via procedures similar to those for surfactants $\mathbf{1}$ and 10, respectively, as reported in the Supporting Information of ref 9. NMR analyses werecarried out on either a $300 \mathrm{MHz}$ Varian or $400 \mathrm{MHz}$ Bruker apparatus. Elemental microanalyses were performed by Atlantic M icrolab, Inc. (N orcross, GA).

Surfactant 1, Bis[2-(F-Hexyl)ethyl]phosphate, Sodium Salt (mp > $220^{\circ} \mathrm{C} ; 53 \%$ yield). ${ }^{1} \mathrm{H}$ NMR $\left(300 \mathrm{MHz}, \delta, \mathrm{CD}_{3} \mathrm{OD}\right)$ : $4.13\left(\mathrm{q}, 4 \mathrm{H} ; \mathrm{J} \mathrm{Hн}=6.6 \mathrm{~Hz}\right.$, J HP $\left.=6.8 \mathrm{~Hz} ; \mathrm{CH}_{2} \mathrm{O}\right), 2.55(\mathrm{tt}, 4 \mathrm{H}$;

(22) Menger, F. M.; Keiper, J . S. Angew. Chem., Int. Ed. Engl. 1998 $37,3443$.

(23) (a) Otake, K.; I mura, T.; Sakai, H.; Abe, M. Langmuir 2001, 17, 3898. (b) Imura, T.; Otake, K.; Hashimoto, S.; Gotoh, T.; Yuasa, M. Yokoyama, S.; Sakai, H.; Rathman, J. F.; Abe, M. Colloids Surf., B 2003, 27, 133.

(24) Senapati, S.; Keiper, J . S.; Wignall, G. D.; Melnichenko, Y. B.; Frielinghaus, H.; DeSimone, J . M.; Berkowitz, M. L. Langmuir 2002 $18,7371$.
$\left.J_{\mathrm{HH}}=6.6 \mathrm{~Hz}, \mathrm{~J} \mathrm{HF}=19.2 \mathrm{~Hz} ; \mathrm{CF}_{2} \mathrm{CH}_{2}\right) .19 \mathrm{~F} \mathrm{NMR}(282 \mathrm{MHz}, \delta$ $\left.\mathrm{CD}_{3} \mathrm{OD}\right):-83.0\left(\mathrm{CF}_{2} \mathrm{CF}_{3}\right),-115.1\left(\mathrm{CH}_{2} \mathrm{CF}_{2}\right),-123.2,-124.2$, $-125.0\left(3 \times \mathrm{CF}_{2}\right),-127.7\left(\mathrm{CF}_{2} \mathrm{CF}_{3}\right)$. $31 \mathrm{P} N \mathrm{NR}\left(121 \mathrm{MHz}, \delta, \mathrm{CD}_{3}\right.$ OD): -0.65 ppm. Anal. Calcd: C, 23.66; $\mathrm{H}, 0.99$. Found: $C, 23.46$; $\mathrm{H}, 1.00$.

Surfactant 2, Bis[2-(F-Octyl)ethyl]phosphate, Sodium Salt (mp > $220{ }^{\circ} \mathrm{C} ; 71 \%$ yield). ${ }^{1} \mathrm{H}$ NMR $\left(300 \mathrm{MHz}, \delta, \mathrm{CD}_{3} \mathrm{OD}\right)$ : $4.13\left(\mathrm{q}, 4 \mathrm{H}\right.$; J нн $=6.3 \mathrm{~Hz}$, J нг $\left.=7.3 \mathrm{~Hz} ; \mathrm{CH}_{2} \mathrm{O}\right), 2.55(\mathrm{tt}, 4 \mathrm{H}$; J нн $=6.3 \mathrm{~Hz}$, J $\left.\mathrm{HF}=19.2 \mathrm{~Hz} ; \mathrm{CF}_{2} \mathrm{CH}_{2}\right)$. ${ }^{19} \mathrm{~F} \mathrm{NMR}\left(282 \mathrm{MHz}, \delta, \mathrm{CD}_{3-}\right.$ $\mathrm{OD}):-83.0\left(\mathrm{CF}_{2} \mathrm{CF}_{3}\right),-114.9\left(\mathrm{CH}_{2} \mathrm{CF}_{2}\right),-123.2,-123.3,-124.1$ $-125.0\left(5 \times \mathrm{CF}_{2}\right),-127.7\left(\mathrm{CF}_{2} \mathrm{CF}_{3}\right)$. $31 \mathrm{P}$ NMR $\left(121 \mathrm{MHz} \delta, \mathrm{CD}_{3}\right.$ OD): 0.90 ppm. Anal. Calcd: C, 23.73; H, 0.80. Found: C, 23.44; $\mathrm{H}, 0.84$.

Surfactant 3, Bis[2-(F-Hexyl)ethyl]phosphate, Ammonium Salt $\left(\mathrm{mp}=200-205^{\circ} \mathrm{C} ; 42 \%\right.$ yield). ${ }^{1} \mathrm{H}$ NMR $(400 \mathrm{MHz}$ $\delta, \mathrm{CD}_{3} \mathrm{OD}$ ): 4.14 (q, 4H; J нн $=6.6 \mathrm{~Hz}$, J нР $\left.=7.2 \mathrm{~Hz} ; \mathrm{CH}_{2} \mathrm{O}\right), 2.55$ $\left(\mathrm{tt}, 4 \mathrm{H} ; J_{\mathrm{HH}}=6.8 \mathrm{~Hz}, J_{\mathrm{HF}}=19.2 \mathrm{~Hz} ; \mathrm{CF}_{2} \mathrm{CH}_{2}\right) .{ }^{19} \mathrm{~F} \mathrm{NMR}(282$ $\left.\mathrm{MHz}, \delta, \mathrm{CD}_{3} \mathrm{OD}\right):-82.9\left(\mathrm{CF}_{2} \mathrm{CF}_{3}\right),-115.0\left(\mathrm{CH}_{2} \mathrm{CF}_{2}\right),-123.4$, $-124.4,-125.2\left(3 \times \mathrm{CF}_{2}\right),-127.8\left(\mathrm{CF}_{2} \mathrm{CF}_{3}\right) .{ }^{31} \mathrm{P} \mathrm{NMR}(121 \mathrm{MHz}$ $\left.\delta, \mathrm{CD}_{3} \mathrm{OD}\right): 0.35 \mathrm{ppm}$. Anal. Calcd: $\mathrm{C}, 23.81 ; \mathrm{H}, 1.50$. Found: $\mathrm{C}$, 23.83; $\mathrm{H}, 1.45$.

Surfactant 4, Bis-[2-(F-Hexyl)ethyl]phosphate, Tetramethylammonium Salt $\left(\mathrm{mp}>220{ }^{\circ} \mathrm{C} ; 35 \%\right.$ yield). ${ }^{1} \mathrm{H}$ NMR $\left(400 \mathrm{MHz}, \delta, \mathrm{CD}_{3} \mathrm{OD}\right): 4.14(\mathrm{q}, 4 \mathrm{H}$; J нH $=6.4 \mathrm{~Hz}$, J н $=6.8 \mathrm{~Hz}$; $\mathrm{CH}_{2} \mathrm{O}$ ), $3.17\left(\mathrm{~s}, 12 \mathrm{H}, \mathrm{N}\left(\mathrm{CH}_{3}\right)_{4}\right), 2.55(\mathrm{tt}, 4 \mathrm{H}$; J H $=6.4 \mathrm{~Hz}$, J HF $\left.=19.2 \mathrm{~Hz} ; \mathrm{CF}_{2} \mathrm{CH}_{2}\right)$. ${ }^{19} \mathrm{~F}$ NMR $\left(282 \mathrm{MHz}, \delta, \mathrm{CD}_{3} \mathrm{OD}\right):-82.9$ $\left(\mathrm{CF}_{2} \mathrm{CF}_{3}\right),-115.0\left(\mathrm{CH}_{2} \mathrm{CF}_{2}\right),-123.4,-124.4,-125.2\left(3 \times \mathrm{CF}_{2}\right)$, $-127.8\left(\mathrm{CF}_{2} \mathrm{CF}_{3}\right)$. ${ }^{31} \mathrm{P} \mathrm{NMR}\left(121 \mathrm{MHz}, \delta, \mathrm{CD}_{3} \mathrm{OD}\right): 0.35 \mathrm{ppm}$. Anal. Calcd: C, 27.83; H, 2.33. Found: C, 27.69; H, 2.46.

Surfactant 5, [2-(F-Hexyl)ethyl]butylphosphate, Sodium Salt ( $\mathrm{mp}>225^{\circ} \mathrm{C}, 31 \%$ yield). ${ }^{1} \mathrm{H}$ NMR $\left(400 \mathrm{MHz}, \delta, \mathrm{CD}_{3} \mathrm{OD}\right)$ : $4.12\left(\mathrm{q}, 2 \mathrm{H}\right.$; J нн $=6.8 \mathrm{~Hz}$, J нр $=7.5 \mathrm{~Hz} ; \mathrm{R}_{\mathrm{F}}$ chain $\left.\mathrm{CH}_{2} \mathrm{O}\right), 3.83$ $\left(\mathrm{q}, 2 \mathrm{H}\right.$; J нH $=5.9 \mathrm{~Hz}$, J $\mathrm{HP}=6.5 \mathrm{~Hz} ; \mathrm{R}_{\mathrm{H}}$ chain $\left.\mathrm{CH}_{2} \mathrm{O}\right), 2.54(\mathrm{tt}, 2 \mathrm{H}$; $\left.\mathrm{J}_{\mathrm{HH}}=6.5 \mathrm{~Hz}, \mathrm{~J} \mathrm{JF}_{\mathrm{HF}}=19.1 \mathrm{~Hz} ; \mathrm{CF}_{2} \mathrm{CH}_{2}\right), 1.58\left(\mathrm{~m}, 2 \mathrm{H} ; \mathrm{CH}_{2} \mathrm{CH}_{2-}\right.$ $\left.\mathrm{CH}_{2} \mathrm{O}\right), 1.41(\mathrm{~m}, 2 \mathrm{H}), 0.92\left(\mathrm{t}, 3 \mathrm{H} ; \mathrm{H}_{\mathrm{H}}=7.0 \mathrm{~Hz}\right),{ }^{19} \mathrm{~F} \mathrm{NMR}(282$ $\left.\mathrm{MHz}, \delta, \mathrm{CD}_{3} \mathrm{OD}\right):-83.0\left(\mathrm{CF}_{2} \mathrm{CF}_{3}\right),-114.9\left(\mathrm{CH}_{2} \mathrm{CF}_{2}\right),-123.2$, $-124.2,-123.0,-127.6\left(\mathrm{CF}_{2} \mathrm{CF}_{3}\right)$. ${ }^{31} \mathrm{P} \mathrm{NMR}(121 \mathrm{MHz}, \delta$, $\left.\mathrm{CD}_{3} \mathrm{OD}\right)$ : 1.54. Anal. Calcd: C, 27.60; H, 2.51. Found: C, 27.35; $\mathrm{H}, 2.62$.

Surfactant 6, [2-(F-Hexyl)ethyl]octylphosphate, Sodium Salt (mp > $225^{\circ} \mathrm{C}, 57 \%$ yield). ${ }^{1} \mathrm{H}$ NMR $\left(400 \mathrm{MHz}, \delta, \mathrm{CD}_{3} \mathrm{OD}\right)$ : $4.15\left(\mathrm{q}, 2 \mathrm{H}\right.$; J нн $=6.5 \mathrm{~Hz}$, J нр $=7.2 \mathrm{~Hz} ; \mathrm{R}_{\mathrm{F}}$ chain $\left.\mathrm{CH}_{2} \mathrm{O}\right), 3.87$ $\left(\mathrm{q}, 2 \mathrm{H}\right.$; J Hн $=6.0 \mathrm{~Hz}$, J HP $=6.4 \mathrm{~Hz} ; \mathrm{R}_{\mathrm{H}}$ chain $\left.\mathrm{CH}_{2} \mathrm{O}\right) 2.59(\mathrm{tt}, 2 \mathrm{H}$; $\left.\mathrm{J}_{\mathrm{HH}}=6.6 \mathrm{~Hz}, \mathrm{~J}_{\mathrm{HF}}=19.1 \mathrm{~Hz} ; \mathrm{CF}_{2} \mathrm{CH}_{2}\right), 1.6\left(\mathrm{~m}, 2 \mathrm{H} ; \mathrm{CH}_{2} \mathrm{CH}_{2-}\right.$ $\left.\left.\left.\mathrm{CH}_{2} \mathrm{O}\right), 1.25-1.43(\mathrm{~m}, 1 \mathrm{H}), 0.91 \mathrm{t}, 3 \mathrm{H} ;\right\rfloor_{\mathrm{HH}}=7.0 \mathrm{~Hz}\right) .{ }^{19} \mathrm{~F} \mathrm{NMR}$ (of acid form) (282 M Hz, $\left.\delta, \mathrm{CDCl}_{3}\right)$ : $-83.0\left(\mathrm{CF}_{2} \mathrm{CF}_{3}\right),-114.9$ $\left(\mathrm{CH}_{2} \mathrm{CF}_{2}\right),-123.2,-124.2,-123.0,-127.6\left(\mathrm{CF}_{2} \mathrm{CF}_{3}\right)$. ${ }^{31} \mathrm{P} \mathrm{NMR}$ (of acid form) (121 MHz, $\left.\delta, \mathrm{CDCl}_{3}\right): 1.38$.

Surfactant 7, [2-(F-Hexyl)ethyl]dodecylphosphate, Sodium Salt ( $\mathrm{mp}>225^{\circ} \mathrm{C}, 62 \%$ yield). ${ }^{1} \mathrm{H}$ NMR (of acid form) (300 MHz, $\delta, \mathrm{CDCl}_{3}$ ): 4.1 (q, $2 \mathrm{H} ; \mathrm{R}_{\mathrm{F}}$ chain $\mathrm{CH}_{2} \mathrm{O}$ ), 3.9 (q, $2 \mathrm{H} ; \mathrm{R}_{\mathrm{H}}$ chain $\left.\mathrm{CH}_{2} \mathrm{O}\right), 2.5\left(\mathrm{~m}, 2 \mathrm{H} ; \mathrm{CF}_{2} \mathrm{CH}_{2}\right), 1.6\left(\mathrm{~m}, 2 \mathrm{H} ; \mathrm{CH}_{2} \mathrm{CH}_{2} \mathrm{CH}_{2} \mathrm{O}\right)$, $1.0-1.4(\mathrm{~m}, 10 \mathrm{H}), 0.89(\mathrm{t}, 3 \mathrm{H}) .{ }^{19} \mathrm{~F}$ N MR (of acid form) $(282 \mathrm{M} \mathrm{Hz}$, $\left.\delta, \mathrm{CDCl}_{3}\right):-83.0\left(\mathrm{CF}_{2} \mathrm{CF}_{3}\right),-114.9\left(\mathrm{CH}_{2} \mathrm{CF}_{2}\right),-123.2,-124.2$, $-123.0,-127.6\left(\mathrm{CF}_{2} \mathrm{CF}_{3}\right)$. 31P NMR (of acid form) (121 MHz, $\delta$, $\left.\mathrm{CDCl}_{3}\right): 1.31$

Surfactant 8, [2-(F-Hexyl)ethyl]hexadecylphosphate, Sodium Salt ( $\mathrm{mp}>225^{\circ} \mathrm{C}, 75 \%$ yield). ${ }^{1} \mathrm{H}$ NMR $(400 \mathrm{MHz}, \delta$, $\left.\mathrm{CD}_{3} \mathrm{OD}\right): 4.14\left(\mathrm{q}, 2 \mathrm{H}\right.$; J нH $=6.8 \mathrm{~Hz}, \mathrm{~J}$ нP $=7.2 \mathrm{~Hz} ; \mathrm{R}_{\mathrm{F}}$ chain $\left.\mathrm{CH}_{2} \mathrm{O}\right)$, 
$3.84\left(\mathrm{q}, 2 \mathrm{H}\right.$; J нH $=6.4 \mathrm{~Hz}$, J нр $=6.4 \mathrm{~Hz} ; \mathrm{R}_{\mathrm{H}}$ chain $\left.\mathrm{CH}_{2} \mathrm{O}\right) 2.56$ $\left(\mathrm{tt}, 2 \mathrm{H}\right.$; J HH $=6.6 \mathrm{~Hz}$, J HF $\left.=18.8 \mathrm{~Hz} ; \mathrm{CF}_{2} \mathrm{CH}_{2}\right), 1.61(\mathrm{~m}, 2 \mathrm{H}$; $\left.\mathrm{CH}_{2} \mathrm{CH}_{2} \mathrm{CH}_{2} \mathrm{O}\right), 1.28-1.38(\mathrm{~m}, 26 \mathrm{H}), 0.89(\mathrm{t}, 3 \mathrm{H}$; J HH $=7.0 \mathrm{~Hz})$. 19F NMR (282 MHz, $\left.\delta, \mathrm{CDCl}_{3}\right):-85.0\left(\mathrm{CF}_{2} \mathrm{CF}_{3}\right),-115\left(\mathrm{CH}_{2} \mathrm{CF}_{2}\right)$, $-120\left(\mathrm{CF}_{2} \mathrm{CF}_{3}\right)$. ${ }^{31} \mathrm{P} N \mathrm{NMR}\left(121 \mathrm{M} \mathrm{Hz}, \delta, \mathrm{CDCl}_{3}\right): 0.0$. Anal. Calcd: C, 41.75; $\mathrm{H}, 5.40$. Found: $C, 42.03 ; \mathrm{H}, 5.46$.

Surfactant 9, [2-(F-Decyl)ethyl]butylphosphate, Sodium Salt (mp > $220{ }^{\circ} \mathrm{C}, 39 \%$ yield). ${ }^{1} \mathrm{H}$ NMR (400 MHz, $\left.\delta, \mathrm{CD}_{3} \mathrm{OD}\right)$ : $4.13\left(\mathrm{q}, 2 \mathrm{H}\right.$; J $\mathrm{HH}=6.5 \mathrm{~Hz}$, J $\mathrm{HP}=7.6 \mathrm{~Hz}$; $\mathrm{R}_{\mathrm{F}}$ chain $\left.\mathrm{CH}_{2} \mathrm{O}\right), 3.83$ $\left(\mathrm{q}, 2 \mathrm{H}\right.$; J HH $=6.0 \mathrm{~Hz}$, J HP $=6.6 \mathrm{~Hz} ; \mathrm{R}_{\mathrm{H}}$ chain $\left.\mathrm{CH}_{2} \mathrm{O}\right), 2.55(\mathrm{tt}, 2 \mathrm{H}$; $\left.\mathrm{J} \mathrm{HH}=6.7 \mathrm{~Hz}, \mathrm{~J} \mathrm{HF}=19.1 \mathrm{~Hz} ; \mathrm{CF}_{2} \mathrm{CH}_{2}\right), 1.59\left(\mathrm{~m}, 2 \mathrm{H} ; \mathrm{CH}_{2} \mathrm{CH}_{2-}\right.$ $\left.\mathrm{CH}_{2} \mathrm{O}\right), 1.40(\mathrm{~m}, 2 \mathrm{H}), 0.92(\mathrm{t}, 3 \mathrm{H}$; J нн $=7.0 \mathrm{~Hz}) .{ }^{19} \mathrm{~F}$ NMR $(282$ $\left.\mathrm{MHz}, \delta, \mathrm{CD}_{3} \mathrm{OD}\right):-83.0\left(\mathrm{CF}_{2} \mathrm{CF}_{3}\right),-114.9\left(\mathrm{CH}_{2} \mathrm{CF}_{2}\right),-123.0$, $-124.0,-125.0\left(7 \times \mathrm{CF}_{2}\right),-127.6\left(\mathrm{CF}_{2} \mathrm{CF}_{3}\right)$. ${ }^{31} \mathrm{P} \mathrm{NMR}(121 \mathrm{MHz}$ $\left.\delta, C D_{3} \mathrm{OD}\right):$ 1.53. Anal. Calcd: C, 26.61; H, 1.81. Found: C, 26.45; $\mathrm{H}, 1.63$.

Surfactant 10, [2-(F-Decyl)ethyl]octylphosphate, Sodium Salt (mp $>225^{\circ} \mathrm{C}, 48 \%$ yield). ${ }^{1} \mathrm{H}$ NMR $(400 \mathrm{MHz}, \delta$, $\left.\mathrm{CD}_{3} \mathrm{OD}\right): 4.13\left(\mathrm{q}, 2 \mathrm{H}\right.$; J HH$=6.3 \mathrm{~Hz}, \mathrm{~J} \mathrm{HP}=7.0 \mathrm{~Hz} ; \mathrm{R}_{\mathrm{F}}$ chain $\mathrm{CH}_{2} \mathrm{O}$ ), $3.82\left(\mathrm{q}, 2 \mathrm{H}\right.$; J нн $=6.5 \mathrm{~Hz}$, J нр $=6.6 \mathrm{~Hz} ; \mathrm{R}_{\mathrm{H}}$ chain $\left.\mathrm{CH}_{2} \mathrm{O}\right), 2.55$ (tt, $2 \mathrm{H}$; J HH $=6.5 \mathrm{~Hz}$, J $\left.\mathrm{HF}=19.6 \mathrm{~Hz} ; \mathrm{CF}_{2} \mathrm{CH}_{2}\right), 1.60(\mathrm{~m}, 2 \mathrm{H}$; $\mathrm{CH}_{2} \mathrm{CH}_{2} \mathrm{CH}_{2} \mathrm{O}$ ), 1.30-1.40 (br m, 10H), 0.87 (t, 3H; J нн $=7.1$ $\mathrm{Hz}) .{ }^{19} \mathrm{~F}$ NMR $\left(282 \mathrm{MHz}, \delta, \mathrm{CD}_{3} \mathrm{OD}\right):-81.4\left(\mathrm{CF}_{2} \mathrm{CF}_{3}\right),-113.3$ $\left(\mathrm{CH}_{2} \mathrm{CF}_{2}\right),-121.4,-122.4,-123.4,\left(7 \times \mathrm{CF}_{2}\right),-126.0\left(\mathrm{CF}_{2} \mathrm{CF}_{3}\right)$. 31P NMR (121 MHz, $\left.\delta, \mathrm{CD}_{3} \mathrm{OD}\right): 1.53$. Anal. Calcd: $\mathrm{C}, 30.86 ; \mathrm{H}$, 2.72. F ound: $C, 30.73 ; \mathrm{H}, 2.62$.

Surfactant 11, [2-(F-Decyl)ethyl]dodecylphosphate, Sodium Salt (mp $>220{ }^{\circ} \mathrm{C}, 30 \%$ yield). ${ }^{1} \mathrm{H} N M R(400 \mathrm{MHz}, \delta$, $\left.\mathrm{CD}_{3} \mathrm{OD}\right): 4.43\left(\mathrm{q}, 2 \mathrm{H}\right.$; J нH $=6.5 \mathrm{~Hz}$, J нP $=7.2 \mathrm{~Hz} ; \mathrm{R}_{\mathrm{F}}$ chain $\mathrm{CH}_{2} \mathrm{O}$ ), $3.83\left(\mathrm{q}, 2 \mathrm{H}\right.$; J нH $=5.9 \mathrm{~Hz}$, J $\mathrm{HP}=6.5 \mathrm{~Hz} ; \mathrm{R}_{\mathrm{H}}$ chain $\left.\mathrm{CH}_{2} \mathrm{O}\right), 2.56$ (tt, $2 \mathrm{H}$; J $\mathrm{HH}=6.5 \mathrm{~Hz}$, J $\left.\mathrm{HF}=19.1 \mathrm{~Hz} \mathrm{CF}_{2} \mathrm{CH}_{2}\right), 1.60(\mathrm{~m}, 2 \mathrm{H}$; $\mathrm{CH}_{2} \mathrm{CH}_{2} \mathrm{CH}_{2} \mathrm{O}$ ), 1.27-1.40 (br m, 18H), 0.88 (t, 3H; J Hн $=7.1$ $\mathrm{Hz}) .{ }^{19}$ F NMR: $\left(282 \mathrm{MHz}, \delta, \mathrm{CD}_{3} \mathrm{OD}\right)-82.9\left(\mathrm{CF}_{2} \mathrm{CF}_{3}\right),-114.9$ $\left(\mathrm{CH}_{2} \mathrm{CF}_{2}\right),-123.0,-124.0,-124.9,\left(7 \times \mathrm{CF}_{2}\right),-127.6\left(\mathrm{CF}_{2} \mathrm{CF}_{3}\right)$. 31P NMR (121 MHz, $\delta, \mathrm{CD}_{3} \mathrm{OD}$ ): 1.54. Anal. Calcd: C, 34.55; $\mathrm{H}$, 3.50. F ound: $C, 34.79 ; \mathrm{H}, 3.39$.

Surfactant 12, [2-(F-Decyl)ethyl]octylphosphate, Ammonium Salt ( $\mathrm{mp}>220^{\circ} \mathrm{C}, 28 \%$ yield). ${ }^{1} \mathrm{H}$ NMR $(400 \mathrm{MHz}, \delta$, $\mathrm{CD}_{3} \mathrm{OD}$ ): $4.12\left(\mathrm{q}, 2 \mathrm{H}\right.$; J HH $=6.8 \mathrm{~Hz}$, J HP $=7.2 \mathrm{~Hz}$; $\mathrm{R}_{\mathrm{F}}$ chain $\mathrm{CH}_{2} \mathrm{O}$ ), $3.83\left(\mathrm{q}, 2 \mathrm{H}\right.$; J HH $=6.4 \mathrm{~Hz}$, J $\mathrm{HP}=6.4 \mathrm{~Hz}$; $\mathrm{R}_{\mathrm{H}}$ chain $\left.\mathrm{CH}_{2} \mathrm{O}\right), 2.58$ (tt, $2 \mathrm{H}$; J нн $=6.4 \mathrm{~Hz}$, J HF $\left.=18.8 \mathrm{~Hz} ; \mathrm{CF}_{2} \mathrm{CH}_{2}\right), 1.61(\mathrm{~m}, 2 \mathrm{H}$; $\mathrm{CH}_{2} \mathrm{CH}_{2} \mathrm{CH}_{2} \mathrm{O}$ ), 1.28-1.37 (br m, 10H), 0.87 (t, 3H; J Hн $=7.2$ $\mathrm{Hz}) .{ }^{19} \mathrm{~F}$ NMR $\left(282 \mathrm{MHz}, \delta, \mathrm{CD}_{3} \mathrm{OD}\right):-82.8\left(\mathrm{CF}_{2} \mathrm{CF}_{3}\right),-115.0$ $\left(\mathrm{CH}_{2} \mathrm{CF}_{2}\right),-123.1,-124.2,-125.1\left(7 \times \mathrm{CF}_{2}\right),-127.7\left(\mathrm{CF}_{2} \mathrm{CF}_{3}\right)$. 31P N MR (121 M Hz, $\left.\delta, C D_{3} \mathrm{OD}\right): 0.98$ ppm. Anal. Calcd: C, 31.06; $H, 3.26$. Found: $C, 31.11 ; H, 3.20$.

Surfactant 13, [2-(F-Decyl)ethyl]octylphosphate, Tetramethylammonium Salt $\left(\mathrm{mp}>220^{\circ} \mathrm{C}, 32 \%\right.$ yield). ${ }^{1} \mathrm{H} N \mathrm{NR}$ $\left(400 \mathrm{M} \mathrm{Hz}, \delta, \mathrm{CD}_{3} \mathrm{OD}\right): 4.12(\mathrm{q}, 2 \mathrm{H}$; J Hн $=6.6 \mathrm{~Hz}$, J HP $=7.2 \mathrm{~Hz}$; $\mathrm{R}_{\mathrm{F}}$ chain $\mathrm{CH}_{2} \mathrm{O}$ ), $3.82\left(\mathrm{q}, 2 \mathrm{H}\right.$; J Hн $=6.4 \mathrm{~Hz}$, J HP $=1.6 \mathrm{~Hz} ; \mathrm{R}_{\mathrm{H}}$ chain $\mathrm{CH}_{2} \mathrm{O}$ ), 2.55 (tt, $2 \mathrm{H}$; J HH $=6.4 \mathrm{~Hz}$, J HF $=18.9 \mathrm{~Hz} ; \mathrm{CF}_{2} \mathrm{CH}_{2}$ ), $1.60\left(\mathrm{~m}, 2 \mathrm{H} ; \mathrm{CH}_{2} \mathrm{CH}_{2} \mathrm{CH}_{2} \mathrm{O}\right), 1.20-1.40(\mathrm{br} \mathrm{m}, 10 \mathrm{H}), 0.87$ (t, 3H; $\mathrm{J} \mathrm{HH}=6.8 \mathrm{~Hz}) .{ }^{19} \mathrm{~F} \mathrm{NMR}\left(282 \mathrm{MHz}, \delta, \mathrm{CD}_{3} \mathrm{OD}\right):-82.8\left(\mathrm{CF}_{2} \mathrm{CF}_{3}\right)$, $-115.0\left(\mathrm{CH}_{2} \mathrm{CF}_{2}\right),-123.1,-124.2,-125.1\left(7 \times \mathrm{CF}_{2}\right),-127.7$ $\left(\mathrm{CF}_{2} \mathrm{CF}_{3}\right)$. ${ }^{31} \mathrm{P} N \mathrm{NR}\left(121 \mathrm{MHz}: \delta, \mathrm{CD}_{3} \mathrm{OD}\right): 0.96 \mathrm{ppm}$. Anal. Calcd: C, 34.75; H, 4.01. Found: C, 34.42; H, 4.47.

Cloud Point Measurements. Cloud point solubilities of surfactants and surfactants and water in carbon dioxide were carried out using a HIP variable volume pressure generator/ view cell (maximum volume $=15 \mathrm{~mL}$ ) containing a $0.5 \mathrm{in}$. thick sapphire window for viewing and a magnetic stir bar to agitate the solution. $\mathrm{CO}_{2}$ (Air Products) was injected with the aid of an ISCO compression pump connected to the cell through high- pressuresteel tubing. Thecell was further attached toa Sensotec pressure transducer and an Omega thermocouple for pressure and temperature readouts, respectively. Measured amounts of surfactant and water were added at room temperature prior to pressurization with $\mathrm{CO}_{2}$. Samples wereheated (controlled to \pm 0.1 ${ }^{\circ} \mathrm{C}$ ) in the cell through the use of variac-controlled heating tape. Cloud points (judged as the reproducible, reversible onset of a visually fully opaque solution) were taken on the cooling cycle by isothermally varying the pressure through volume changes facilitated by the hand-control led piston. The cell was tipped at a downward angletoaid in theobservation of any phase-separated liquids. The cell was cleaned thoroughly between experiments.

UV-vis. ${ }^{9}$ UV - vis spectra wereacquired using a Perkin-EImer Lambda 40 spectrometer. Pressurized solutions were prepared in a $2.5 \mathrm{~mL}$ stainless steel cell, equpped with two 1 in. diameter $\times 5 / 8$ in. thick sapphire windows enclosing a $1 \mathrm{~cm}$ solution path length. Appropriateamounts of surfactant and water were placed into the cell chamber, along with a $1 / 4$ in. magnetic stir bar for agitation. A film of methyl orange (for a concentration of $5 \times 10^{-5}$ M) was precast and dried on one of the sapphire windows by addition of a stock solution via syringe. The chamber wastightly sealed, and the cell was pressurized and stirred until a clear, one-phase solution was present.

Small-Angle Neutron Scattering (SANS). SANS measurements were carried out on the KWS2 SANS facility at the FRJ 2 reactor in J ülich, Germany, as described in detail above. $\mathrm{CO}_{2}$ (Air Liquide) was pressurized using an HIP stainless steel generator, with aid of readings from a Sensotec pressure transducer. The temperature of the stainless steel solution chamber ( $5.6 \mathrm{~mL}$ volume) was controlled with electric heating sleeves. Sample solutions were prepared by loading the surfactant, $\mathrm{D}_{2} \mathrm{O}$ (Cambridge I sotopes), and a "flea" magnetic stir bar to agitate the materials after injection of $\mathrm{CO}_{2}$.

Microscopy. Surfactant samples ( $1 \mathrm{mg})$ were smeared on a borosilicate glass microscope slide with a spatula, hydrated with $\sim 200 \mu \mathrm{L}$ of Milli-Q deionized water, and covered with a thin glass coverslip. Samples were allowed to hydrate at room temperature for a few minutes and weresubsequently evaluated using a Nikon Diaphot TMD (phase contrast mode) outfitted with an Optronics digital camera and I mage Pro Plus software.

Acknowledgment. This work was supported by the Kenan Center for the Utilization of Carbon Dioxide in Manufacturing and the STC Program of the National ScienceF oundation under Agreement CHE-9876674. The research at Oak Ridge was supported by the Division of Materials Sciences, under Contract No. DE-AC0500OR22725 with the Oak Ridge National Laboratory, managed by UT-Battelle, LLC. SANS experiments were carried out at the KWS-2 facility at F orschungszentrum J ülich.J .S.K., G.D.W., Y.B.M. and G.W.L. wish to thank Professor D. Richter for the hospitality and assistance provided by the staff of the FZ]. Weal so thank Professor F. Menger (Emory University) for use of the optical microscope.

Supporting Information Available: Data and discussion on waterless surfactant $-\mathrm{CO}_{2}$ solutions, cloud point profiles, and core radius vs volume of $\mathrm{D}_{2} \mathrm{O}$. This material is availablefree of charge via the Internet at http://pubs.acs.org.

LA034742S 